\title{
Penetrance and disease expression of (likely) pathogenic variants associated with inherited cardiomyopathies in the general population
}

Mimount Bourfiss, MD ${ }^{a *}$; Marion van Vugt, MSc ${ }^{\text {**; }}$ Abdulrahman I. Alasiri, MSc ${ }^{a}$; Bram Ruijsink, MD, $\mathrm{PhD}^{\mathrm{a}, \mathrm{b}}$; Jessica van Setten, MSc, PhD; ; Amand F. Schmidt, MSc, PhD ${ }^{\mathrm{a}, \mathrm{c}}$; Dennis Dooijes, PhD ${ }^{\mathrm{d}}$; Esther

Puyol-Antón, PhD' ; Birgitta K. Velthuis, MD, PhD'; J. Peter van Tintelen, MD, PhD ; Anneline S.J.M. te

Riele, MD, PhD ${ }^{a, f}$; Annette F. Baas, MD, PhD ; Folkert W. Asselbergs, MD, PhD ${ }^{a, c, g}$.

*Shared first authorship

Affiliations

a. Department of Cardiology, University Medical Center Utrecht, Utrecht University, Utrecht, the Netherlands

b. School of Biomedical Engineering and Imaging Sciences, King's College London, London, United Kingdom

c. Institute of Cardiovascular Science, London, Faculty of Population Health Sciences, University College London, United Kingdom

d. Department of Genetics, University Medical Center Utrecht, Utrecht, Utrecht University, Utrecht, the Netherlands

e. Department of Radiology, University Medical Center Utrecht, Utrecht University, Utrecht, the Netherlands

f. Netherlands Heart Institute, Utrecht, the Netherlands

g. Health Data Research UK and Institute of Health Informatics, University College London, London, United Kingdom

Short title: ACM, DCM and HCM variants in the general population

Corresponding author: Mimount Bourfiss; Department of Medicine, Division of Cardiology;

University Medical Center Utrecht; room E.02.561; Heidelberglaan 100; 3584 CX Utrecht, the

Netherlands. Email address: m.bourfiss-2@umcutrecht.nl Telephone number: +31-88-77570240. Fax

number: $+31-88-7555660$.

Journal Subjects Terms: Cardiomyopathy, Genetics, Heart failure, Hypertrophy, Magnetic Resonance imaging 
medRxiv preprint doi: https://doi.org/10.1101/2022.01.06.22268837; this version posted January 6, 2022. The copyright holder for this preprint (which was not certified by peer review) is the author/funder, who has granted medRxiv a license to display the preprint in perpetuity.

It is made available under a CC-BY-NC 4.0 International license .

\begin{abstract}
Background. (Likely) pathogenic variants associated with arrhythmogenic cardiomyopathy ( $\mathrm{ACM})$, dilated cardiomyopathy (DCM) and hypertrophic cardiomyopathy ( $\mathrm{HCM}$ ) are recommended to be reported as secondary findings in genome sequencing studies. This provides opportunities for early diagnosis, but also fuels uncertainty in variant carriers $(G+)$, since disease penetrance is incomplete. We assessed the prevalence and disease expression of $\mathrm{G}+$ in the general population.
\end{abstract}

Methods. We identified (likely) pathogenic variants associated with ACM, DCM and/or HCM in 200,643 UK Biobank individuals, who underwent whole exome sequencing. We calculated the prevalence of $\mathrm{G}+$ and analysed the frequency of cardiomyopathy/heart failure diagnosis. In undiagnosed individuals, we analysed early signs of disease expression.

Results. We found a prevalence of 1:578, 1:251 and 1:149 for (likely) pathogenic variants associated with ACM, DCM and HCM respectively. Compared to controls, cardiovascular mortality was higher in DCM G+ (OR 1.67 [95\% Cl 1.04;2.59], $p=0.030)$, but similar in ACM

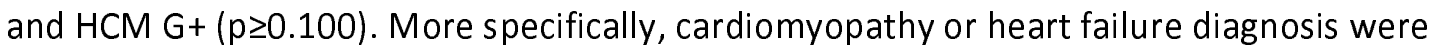
more frequent in DCM G+ (OR $\left.3.66[95 \% \mathrm{Cl} 2.24 ; 5.81], \mathrm{p}=4.9 \bullet 10^{-7}\right)$ and $\mathrm{HCM} \mathrm{G}+(\mathrm{OR} 3.03$ [95\% $\left.\mathrm{Cl} 1.98 ; 4.56], p=5.8 \cdot 10^{-7}\right)$, but comparable in ACM G+ (p=0.172). In contrast, ACM G+ had more ventricular arrhythmias $\left(p=3.3 \cdot 10^{-4}\right)$. In undiagnosed individuals, left ventricular ejection fraction was reduced in DCM G+ $(p=0.009)$.

Conclusions. In the general population, (likely) pathogenic variants associated with ACM, DCM or HCM are not uncommon. Although G+ have increased mortality and morbidity, disease expression in these carriers from the general population remains low. Decisions on application of cascade screening and frequency of cardiological examination should be based on multiple factors, such as the variant and disease expression. 
medRxiv preprint doi: https://doi.org/10.1101/2022.01.06.22268837; this version posted January 6, 2022. The copyright holder for this preprint (which was not certified by peer review) is the author/funder, who has granted medRxiv a license to display the preprint in perpetuity.

It is made available under a CC-BY-NC 4.0 International license .

Key Words: whole exome sequencing, genetics, arrhythmogenic cardiomyopathy, dilated cardiomyopathy, hypertrophic cardiomyopathy

\section{Background}

The major inherited cardiomyopathies arrhythmogenic cardiomyopathy (ACM), dilated cardiomyopathy (DCM) and hypertrophic cardiomyopathy (HCM) are characterized by ventricular dysfunction and ventricular arrhythmias that can lead to progressive heart failure and sudden cardiac death ${ }^{1}$. ACM - especially its right dominant subform - is mainly caused by pathogenic variants in desmosomal genes, whereas DCM and HCM are mainly caused by sarcomeric gene variants ${ }^{2}$. These inherited cardiomyopathies are typically inherited in an autosomal dominant fashion with incomplete penetrance and variable expressivity. As such, phenotypic expression may vary greatly, even among individuals from the same family or those carrying the same pathogenic variant.

With the implementation of next-generation sequencing (NGS), genetic testing has become an important part of routine clinical care in the diagnosis of inherited cardiomyopathies ${ }^{3}$. Technical advances and commercial availability of NGS, have led to less costly and more accessible genetic testing. The American College of Medical Genetics and Genomics (ACMG) has developed recommendations for the reporting of incidental or secondary findings unrelated to the test indication ${ }^{4}$. In this framework, variants in genes associated with ACM, DCM and $\mathrm{HCM}$ are recommended to be reported as secondary findings from clinical exome and other genome sequencing tests ${ }^{4}$. Although this offers the potential to prevent morbidity and mortality of heart failure and sudden cardiac death by 
medRxiv preprint doi: https://doi.org/10.1101/2022.01.06.22268837; this version posted January 6, 2022. The copyright holder for this preprint (which was not certified by peer review) is the author/funder, who has granted medRxiv a license to display the preprint in perpetuity.

It is made available under a CC-BY-NC 4.0 International license.

early treatment, it also fuels uncertainty in (likely) pathogenic variant carriers $(G+)$ and their family members, since factors that influence disease penetrance in the general population are largely unknown. More knowledge about disease penetrance of these variants in an unselected population cohort is needed to determine screening protocols in these individuals.

In this study, we aimed to assess the G+ prevalence in the general population using a set of recently curated genes for $\mathrm{ACM}, \mathrm{DCM}$ and $\mathrm{HCM}^{5-7}$ in two (inter)national databases ${ }^{8,9}$. In order to do so, we leveraged data from the UK Biobank (UKB), a population-based cohort with whole exome sequencing (WES) data available of 200,643 individuals ${ }^{10}$. Furthermore, we looked into the UKB-reported phenotypical characteristics of these G+ and assessed the occurrence of early signs of disease in undiagnosed $\mathrm{G}+$.

\section{Methods}

Genetic variants in the study population

We identified carriers of a (likely) pathogenic variant associated with ACM, DCM or HCM in individuals from the UKB who underwent WES ( $n=200,643$ at time of analysis). For each inherited cardiomyopathy we selected curated genes classified to have definite, strong or moderate evidence of pathogenicity ${ }^{5-7}$. For $A C M$ we included DES, DSC2, DSG2, DSP, JUP, PKP2, PLN and TMEM43; for DCM we included ACTC1, ACTN2, BAG3, DES, DSP, FLNC, JPH2, LMNA, MYH7, NEXN, PLN, RBM20, SCN5A, TNNC1, TNNI3, TNNT2, TPM1, TTN and VCL; and for HCM we included ACTC1, CSRP3, JPH2, MYBPC3, MYH7, MYL2, MYL3, TNNC1, TNNI3, TNNT2 and TPM1 (Figure 1 and Table S1). Some variants are associated with two cardiomyopathies (Figure 1 and Table S1); individuals carrying these variants were included in the $\mathrm{G}+$ groups of both cardiomyopathies. Next, likely pathogenic and pathogenic variants 
medRxiv preprint doi: https://doi.org/10.1101/2022.01.06.22268837; this version posted January 6, 2022. The copyright holder for this preprint (which was not certified by peer review) is the author/funder, who has granted medRxiv a license to display the preprint in perpetuity.

It is made available under a CC-BY-NC 4.0 International license.

in these genes were identified using the ClinVar NCBI-NIH database ${ }^{8}$ and the Dutch Society for Clinical Genetic Laboratory Diagnostics (Vereniging Klinische Genetische Laboratoriumdiagnostiek, VKGL) database ${ }^{9}$. An elaborate overview of the Clinvar and VKGL search criteria is given in Figure 2. In short, ClinVar was queried using the disease name(s) and filtered for (likely) pathogenic variants in the curated genes. For pathogenic variants mentioned in the VKGL database, which does not specify disease associations, association with one of the cardiomyopathies was confirmed in ClinVar. The minor allele frequency (MAF) cut-off was defined at 0.001. Pathogenic variants were classified as missense or loss of function (LoF), with LoF being defined as frameshift, stop gain, start lost and canonical splice site variants.

We matched G+ individuals in a 1:4 ratio to UKB individuals without a (likely) pathogenic variant associated with one of the cardiomyopathies (G-). Matching of this Gcontrol group was based on age, sex, ethnicity and presence of cardiac magnetic resonance imaging (CMR) measurements. Controls are referred to as G- throughout this study.

\section{Data extraction UKB}

\section{Disease definitions}

An elaborate overview of the disease definitions used in this study is available in Table S2. In short, individuals were defined to be phenotype positive $(\mathrm{P}+)$ if they had an ICD-10 or selfreporting code for cardiomyopathy, DCM, HCM or heart failure, without a diagnosis of chronic ischemic heart disease. No ICD-10 or self-reporting code was available for ACM in the UKB.

\section{CMR and ECG data analysis}


medRxiv preprint doi: https://doi.org/10.1101/2022.01.06.22268837; this version posted January 6, 2022. The copyright holder for this preprint (which was not certified by peer review) is the author/funder, who has granted medRxiv a license to display the preprint in perpetuity.

It is made available under a CC-BY-NC 4.0 International license.

We investigated disease expression on cardiac magnetic resonance imaging (CMR) and electrocardiography (ECG) in a subset of G+P- individuals. The full CMR protocol of the UKB has been described in detail ${ }^{11}$. In short, all CMR examinations were performed on a 1.5 Tesla scanner (Magnetom Aera, Syngo Platform VD13A, Siemens Healthcare, Erlangen, Germany). We used a previously developed and validated deep-learning methodology (Al-CMR ${ }^{\mathrm{QC}}$ ) to extract left (LV) and right ventricular (RV) CMR measurements ${ }^{12}$. In short, cine images of short-axis and 2- and 4-chamber long-axis views were used to automatically calculate LV and RV functional measures (ejection fraction [EF], stroke volume [SV]) and structural measures (end diastolic volume [EDV], end-systolic volume [ESV], LV end diastolic mass [EDM], LV mass to EDV ratio [LVMVR] and LV maximal and regional [16 segments model according the American Heart Association $\left.{ }^{13}\right]$ wall thickness).

The electrocardiography (ECG) variables P duration, $\mathrm{P}$ axis, $\mathrm{PQ}$ interval, QRS duration, $\mathrm{R}$ axis, QTc interval and T axis were extracted from the UKB for G+P-individuals.

\section{Statistical analysis}

Statistical analysis was performed using R version $4.0 .2^{14}$. Continuous values are presented as median [interquartile range] and for comparisons of two groups, Mann-Whitney-U test was used. Categorical data was displayed as absolute frequency (n) and percentages (\%) and Fisher's exact test was used to test for differences. The strength of the association between cardiac outcomes and G+ ACM, DCM and HCM was calculated by the odds ratio with 95\% confidence intervals. A p-value of less than 0.05 was considered significant. See the Supplemental Information for a more elaborate overview of the definitions and analysis performed. 
medRxiv preprint doi: https://doi.org/10.1101/2022.01.06.22268837; this version posted January 6, 2022. The copyright holder for this preprint (which was not certified by peer review) is the author/funder, who has granted medRxiv a license to display the preprint in perpetuity.

It is made available under a CC-BY-NC 4.0 International license.

\section{Results}

Population characteristics

We identified 2,207/200,643 unique $G+$ individuals classified as 1$) A C M ~ G+(n=347,54 \%$ female, median age of 57 [50-64] years); 2) DCM G+ ( $n=800,56 \%$ female, median age of 58 [51-64] years) and; 3) HCM G+ ( $n=1,346,54 \%$ female, median age of 56 [49-63] years). The matched control group consisted of 9,972 individuals (55\% females, median age of 57 [4963] years). Table 1 and Table S3 show the baseline characteristics of the included individuals. The majority of G+ were of white ethnicity (ACM 90\%, DCM 96\%, HCM 75\%), followed by asian (ACM 3\%, DCM 1\%, HCM 19\%) and black ethnicity (ACM 2\%, DCM 2\% and HCM 2\%).

Genotypic characteristics of (likely) pathogenic variant carriers

Prevalence of (likely) pathogenic variants in the general population

We found a prevalence of $1: 578$ [1:521; $1: 644]$ ACM G+ and identified 75 variants out of the 593 (13\%) (likely) pathogenic variants described in Clinvar and VKGL: 13 missense and 62 LoF (Table S4). As shown in Figure 3, most ACM G+ harbored a pathogenic variant in PKP2 ( $n=185,53 \%)$, followed by DSP ( $n=49,14 \%), D S C 2(n=42,12 \%), D S G 2(n=31,9 \%), J U P(n=24$, 7\%), DES ( $\mathrm{n}=15,4 \%)$, and $\operatorname{PLN}(\mathrm{n}=1,0.3 \%)$.

We found a prevalence of $1: 251$ [1:234; 1:269] DCM G+ and identified 216 out of 3,460 (6\%) (likely) pathogenic variants described in Clinvar and VKGL: 80 missense and 136 LoF (Table S4). Variants in $T T N(n=272,34 \%)$ and $M Y H 7(n=158,20 \%)$ were most prevalent among DCM G+, followed by SCN5A ( $\mathrm{n}=59,7 \%), \operatorname{FLNC}(\mathrm{n}=56,7 \%), D S P(\mathrm{n}=49,6 \%), D E S$ ( $n=49,6 \%)$, LMNA ( $n=42,5 \%)$, TNNI3 ( $n=35,4 \%)$ and TNNT2 ( $n=32,4 \%)$. Eight more genes 
medRxiv preprint doi: https://doi.org/10.1101/2022.01.06.22268837; this version posted January 6, 2022. The copyright holder for this preprint (which was not certified by peer review) is the author/funder, who has granted medRxiv a license to display the preprint in perpetuity.

It is made available under a CC-BY-NC 4.0 International license.

with a frequency of less than $3 \%$ were identified: BAG3, PLN, TNNC1, ACTN2, RBM20, NEXN, TPM1, and ACTC1 (Figure 3).

We found a prevalence of 1:149 [1:141; 1:157] HCM G+ and identified 131 out of 1,512 (9\%) (likely) pathogenic variants from Clinvar and VKGL: 98 missense and 23 LoF

(Table S4). Most individuals carried a (likely) pathogenic variant in MYBPC3 ( $n=723,54 \%)$, followed by TNNT2 ( $n=274,20 \%), M Y H 7$ ( $n=232,17 \%)$, and TNNI3 ( $n=50,4 \%)$ (Figure 3). A frequency of less than $3 \%$ was found in CSRP3, MYL2, TNNC1, JPH2, TPM1, ACTC1, and MYL3 (Figure 3). Interestingly, a variant in TNNT2 (c.862C>T p.Arg288Cys) affected 242 individuals (18\%). Four of these carriers were diagnosed with heart failure, of whom one also with $\mathrm{HCM}$. All of them also suffered from chronic ischemic heart disease. Furthermore, a variant in MYBPC3 (c.3628-41_3628-17del) was mainly seen in individuals with an Asian ethnicity ( $n=237,18 \%$ of the total HCM G+). Four were diagnosed with heart failure, of whom two also had coronary artery disease and one was diagnosed with DCM, however none were diagnosed with HCM. When excluding these two variants, we found a HCM G+ prevalence of 1:250 [1:234; $1: 269]$. MYBPC3 remained the most prevalent gene (52\%), whereas the TNNT2 frequency decreased to $4 \%$.

The prevalence of $\mathrm{G}+$ per gene for all cardiomyopathies is depicted in Table $\mathbf{S 5}$.

\section{Overlapping variants and individuals}

Some (likely) pathogenic variants were identified in multiple cardiomyopathy subtypes.

First, 26 (likely) pathogenic variants were described in both ACM and DCM, affecting 53 individuals. Most of these variants ( $n=20 / 26$ variants, $77 \%)$ were found in $D S P(n=37$ individuals, $70 \%$ ), of whom one individual (3\%) had heart failure and one (3\%) was diagnosed with cardiomyopathy. Five variants out of $26(19 \%)$ were found in DES ( $n=15$ 
medRxiv preprint doi: https://doi.org/10.1101/2022.01.06.22268837; this version posted January 6, 2022. The copyright holder for this preprint (which was not certified by peer review) is the author/funder, who has granted medRxiv a license to display the preprint in perpetuity.

It is made available under a CC-BY-NC 4.0 International license .

individuals, $28 \%$ ) of whom two individuals (13\%) had heart failure, and one was diagnosed with both DCM and HCM. One variant out of 26 (4\%) in PLN (c.26G>A; p.Arg9His, NM_002667.5) was found in one individual (2\%) who was not diagnosed with either a cardiomyopathy or heart failure.

Second, 52 (likely) pathogenic variants were described in DCM and HCM, affecting 232 individuals. Most of these variants ( $n=33 / 52$ variants, $63 \%)$ were found in $M Y H 7(n=158$ individuals, $68 \%$ ), followed by 10 variants (19\%) in TNNT2 ( $n=29$ individuals, $13 \%$ ), 6 variants (12\%) in TNNI3 ( $\mathrm{n}=35$ individuals, 15\%), and 1 (2\%) variant in TNNC1, ACTC1 as well as TPM1. In this group of 232 individuals, $9(4 \%)$ individuals had a cardiomyopathy or heart failure diagnosis, of whom 5 were diagnosed with HCM and none with DCM.

Furthermore, three individuals carried two pathogenic variants. Individual 1 carried variants in MYBPC3 (c.3628-41_3628-17del, NM_000256.3) and TNNT2 (c.460C>T; p.Arg154Trp, NM_001276345.2) and was diagnosed with heart failure, with underlying chronic ischemic heart disease. Individual 2 carried variants in FLNC (c.7450G>A; p.Gly2484Ser, NM_001458.5) and PKP2 (c.1867G>T; p.Glu623Ter, NM_001005242.3) and was therefore incuded in both the ACM as well as the DCM G+ group. Individual 3 carried variants in MYBPC3 (c.1504C>T; p.Arg502Trp, NM_000256.3) and MYH7 (c.5655G>A; p.Ala1885=, NM_000257.4). Individuals 2 and 3 were not diagnosed with either cardiomyopathy or heart failure.

Phenotypic characteristics of (likely) pathogenic variant carriers

\section{Cardiovascular risk factors}

Hypertension, BMI, and level of activity in metabolic equivalent of task minutes (MET) per week were comparable between G- and G+ for all cardiomyopathies ( $p \geq 0.055$; Table 1 and 
medRxiv preprint doi: https://doi.org/10.1101/2022.01.06.22268837; this version posted January 6, 2022. The copyright holder for this preprint (which was not certified by peer review) is the author/funder, who has granted medRxiv a license to display the preprint in perpetuity. It is made available under a CC-BY-NC 4.0 International license.

Table S6). Diabetes was more prevalent in $\mathrm{G}+\mathrm{HCM}(9.2 \%$ (G-) vs $11.4 \%(\mathrm{G}+), \mathrm{p}=0.008)$, while smoking was more prevalent in DCM G+ $(41.4 \%$ vs $46.4 \%, p=0.007)$ (Table S7).

\section{Cardiovascular disease}

As seen in Figure 4 and Table S7, compared to G-, cardiomyopathy/heart failure without previous ischemic heart disease $(\mathrm{P}+)$ was more often diagnosed in DCM G+ $(\mathrm{OR} 3.66[95 \% \mathrm{Cl}$ 2.24;5.81], $\left.p=4.9 \cdot 10^{-7}\right)$ and HCM G+ (OR 3.03 [95\% Cl 1.98;4.56], $\left.p=5.8 \bullet 10^{-7}\right)$. Among DCM G+, 25 individuals (3.1\%, genes: 8 MYH7, 8 TTN, 2 BAG3, 2 DSP, 2 FLNC, 1 DES, 1 SCN5A and 1 TNNT2) were P+. Within HCM G+, 32 individuals (4.0\%, genes: 20 MYBPC3, 10 MYH7, 1 TNNI3 and 1 TNNT2) were P+. For ACM G+, 4 individuals (1.2\%, genes: 2 DSP, 1 DES and 1 PKP2) were $\mathrm{P}+$, being comparable to $\mathrm{G}$ - controls ( 87 subjects, $0.8 \%$ ).

Ventricular arrhythmias occurred more often in G+ compared to G-, reaching statistical significance for ACM (OR $6.20[95 \% \mathrm{Cl} 2.30 ; 14.38], \mathrm{p}=3.3 \cdot 10^{-4}$ ) and DCM (OR 4.97 $\left.[95 \% \mathrm{Cl} 2.39 ; 9.75], \mathrm{p}=1.9 \cdot 10^{-5}\right)$. Atrial arrhythmias were more prevalent among $\mathrm{DCM} \mathrm{G}+(\mathrm{OR}$ $2.27[95 \% \mathrm{Cl} 1.52 ; 3.31], \mathrm{p}=8.2 \cdot 10^{-5}$ ). Finally, all-cause mortality (OR 1.39 [95\% Cl 1.02;1.85], $\mathrm{p}=0.032)$ and death due to a cardiovascular cause were more prevalent in DCM G+ (OR 1.67 [95\% Cl 1.04;2.59], $\mathrm{p}=0.030$ ) but did not reach statistical significance for ACM G+ and HCM $\mathrm{G}+(\mathrm{p} \geq 0.100)$. Figure 5 depicts the overlap in cardiomyopathy, heart failure, ventricular arrhythmia and ischemic heart disease diagnosis. See Figure S1 for the forest plots when excluding the more prevalent TNNT2 and MYBPC3 variants in $\mathrm{HCM} \mathrm{G+} \mathrm{individuals.}$ 
medRxiv preprint doi: https://doi.org/10.1101/2022.01.06.22268837; this version posted January 6, 2022. The copyright holder for this preprint (which was not certified by peer review) is the author/funder, who has granted medRxiv a license to display the preprint in perpetuity.

It is made available under a CC-BY-NC 4.0 International license.

Next, we set out to study early signs of disease in $\mathrm{G}+$ without a cardiomyopathy/heart failure diagnosis (P-) using registered ICD-10 codes, self-reported cardiac symptoms, and abnormal ECG and CMR values.

\section{Diagnosis and symptoms}

Ventricular arrhythmias were more prevalent in ACM G+P- (OR 5.85 [95\% Cl 1.98;14.40], $p=0.001)$ and $D C M$ G+P- (OR 3.43 [95\% Cl 1.35;7.68], p=0.005) but not in HCM G+P- (OR 1.01 [95\% $\mathrm{Cl} 0.26 ; 2.86], \mathrm{p}=1.000$ ) compared to G-P- controls. Also, atrial arrhythmias (OR 2.12 [95\% $\mathrm{Cl} 1.36 ; 3.19], p=7.9 \cdot 10^{-4}$ ) were more frequent in DCM G+P- compared to G-P- controls. Finally, angina pectoris occurred more often in HCM G+P- (OR 1.38 [95\% Cl 1.01;1.85], $p=0.038)$, but not in ACM G+P- and DCM G+P- ( $p \geq 0.117$; Table S6).

\section{Electrocardiography}

In total, 231 out of 2,207 G+P- and 1,058 out of 9,885 G-P- had various ECG variables available. None of these ECG variables differed significantly between all undiagnosed G+ and control individuals (Table S7).

\section{Cardiac magnetic resonance imaging}

CMR data was available in $225 \mathrm{G}+\mathrm{P}$ - of the 2,207 unique $\mathrm{G}+\mathrm{P}$ - individuals: $\mathrm{n}=33$ for $\mathrm{ACM}$ G+P-, $n=87$ for DCM G+P- and n=130 for HCM G+P-) and 986 of the 9,885 G-P- controls.

As shown in Figure 6 and Table S7, all RV ( $p \geq 0.546)$ and LV ( $p \geq 0.052)$ functional and structural parameters in ACM G+P- were comparable to G-P-controls. Three ACM G+Pindividuals had an RVEDV corrected for body surface area (RVEDVi) between $100-110 \mathrm{~mL} / \mathrm{m}^{2}$ for males or $90-100 \mathrm{~mL} / \mathrm{m}^{2}$ for females, meeting the minor CMR task force criteria (TFC) if 
medRxiv preprint doi: https://doi.org/10.1101/2022.01.06.22268837; this version posted January 6, 2022. The copyright holder for this preprint (which was not certified by peer review) is the author/funder, who has granted medRxiv a license to display the preprint in perpetuity.

It is made available under a CC-BY-NC 4.0 International license .

wall motion abnormalities were present, and two ACM G+P- individuals had an RVEDVi larger than $110 \mathrm{~mL} / \mathrm{m}^{2}$ for males or $100 \mathrm{~mL} / \mathrm{m}^{2}$ for females, meeting the major CMR TFC ${ }^{15}$. In addition, $\mathrm{ACM} \mathrm{G}+\mathrm{P}$ - had reduced inferior and posterolateral wall thickness compared to controls $(p \leq 0.035)$.

Overall, DCM G+P- and G-P- controls had comparable RV functional and structural measures ( $p \geq 0.048)$. However, DCM G+P- had lower LVEF $(57.3 \%[52.6,62.8]$ vs. $59.5 \%$ $[55.3,63.5]$ vs, $p=0.009)$ and less negative LV peak longitudinal strain $(-22.3 \%[-24.6,-19.86]$ vs. $-23.3 \%$ [-26.0, -21.4$], \mathrm{p}=0.009)$. Although LVEDVi was not significantly increased in DCM G+P-, the LVEDV/RVEDV ratio $\left(0.9[0.9,1.0]\right.$ vs $\left.1.0[0.9,1.1], p=8.2 \cdot 10^{-4}\right)$ and LVESVi $(30.0$ $\mathrm{ml} / \mathrm{m}^{2}$ [25.1, 35.7] vs $31.7 \mathrm{ml} / \mathrm{m}^{2}$ [26.2, 39.8], $\left.\mathrm{p}=0.032\right)$ were increased. Six individuals had an LVEF below $45 \%$, but none of the individuals met the Henry criteria for DCM (LVEF below $45 \%$ and LVEDVi two times the normal SD) ${ }^{16}$.

For HCM G+P-, most RV and LV functional and dimension parameters were comparable to G-P- controls ( $p \geq 0.051$ ). Only RVEF was higher than controls (58.4\% [54.2, $62.7]$ vs $59.6 \%[54.8,64.0], p=0.025)$. Importantly, wall thickness was not significantly different between HCM G+P- without a cardiomyopathy/heart failure diagnosis and G-P$(p \geq 0.160)$. None of the $G+P$ - individuals met $\mathrm{HCM}$ criteria ${ }^{17}$ of $\geq 15 \mathrm{~mm}$ wall thickness, but two individuals met the criteria for limited hypertrophy $(13-15 \mathrm{~mm})$ in the presence of a positive genetic test ${ }^{17}$.

\section{Exclusion of the more prevalent TNNT2 and MYBPC3 variants}

When excluding the more prevalent TNNT2 and $M Y B P C 3$ variants in $\mathrm{HCM} \mathrm{G+P-individuals,}$ the occurrence of ventricular arrhythmias (OR $1.72[95 \% \mathrm{Cl} 0.44 ; 4.89], \mathrm{p}=0.306$ ) and atrial arrhythmias (OR 1.43 [95\% Cl 0.84;2.32], p=0.156) was comparable to G-P-controls. 
medRxiv preprint doi: https://doi.org/10.1101/2022.01.06.22268837; this version posted January 6, 2022. The copyright holder for this preprint (which was not certified by peer review) is the author/funder, who has granted medRxiv a license to display the preprint in perpetuity. It is made available under a CC-BY-NC 4.0 International license.

However, the maximum wall thickness $(8.47 \mathrm{~mm}[7.59,9.94]$ vs. $8.09 \mathrm{~mm}[7.24,9.01]$, $p=0.008)$ and basal anterior wall thickness $(7.93 \mathrm{~mm}[6.97,9.11]$ vs. $7.65 \mathrm{~mm}[6.81,8.49], p$ $=0.029$ ) were significantly increased in HCM G+P- compared to controls (Table S7). Two individuals had a maximum wall thickness between $13-15 \mathrm{~mm}$.

\section{Discussion}

In this study we leveraged the largest European population database including WES and phenotyping data to evaluate the prevalence and penetrance of previously reported (likely) pathogenic variants associated with $A C M, D C M$ and HCM. Our study has several interesting findings. First, we found a prevalence of 1:578, 1:251, and 1:149 for (likely) pathogenic variants previously associated with $A C M, D C M$ and $H C M$ respectively. Second, $1.2 \%$ of $A C M$ $\mathrm{G}+, 3.1 \%$ of DCM G+ and $2.6 \%$ of $\mathrm{HCM} \mathrm{G}+$ were diagnosed with a cardiomyopathy or heart failure without previous chronic ischemic heart disease. Finally, $3.2 \%$ of the undiagnosed ACM G+, $1.8 \%$ of the undiagnosed DCM G+, $0.5 \%$ of the undiagnosed HCM G+ reported ventricular arrhythmias or had CMR abnormalities. These results confirm the low disease penetrance in $\mathrm{G}+$ among the general population.

Prevalence of pathogenic variant carriers in the general population

Since the major contributor to inherited cardiomyopathies are rare genetic variants, a large dataset is needed to accurately identify the population prevalence of these variants.

Although prevalence of pathogenic variants in populations has been the focus of several previous studies $^{4,18-20}$, they were mostly limited by the number of included individuals. At time of analysis, we had access to an unprecedented high number of 200,643 individuals. 
medRxiv preprint doi: https://doi.org/10.1101/2022.01.06.22268837; this version posted January 6, 2022. The copyright holder for this preprint (which was not certified by peer review) is the author/funder, who has granted medRxiv a license to display the preprint in perpetuity.

It is made available under a CC-BY-NC 4.0 International license .

The reported prevalence of $\mathrm{ACM} \mathrm{G}+$ in the general population varied widely between different previous studies, ranging between $1: 143$ to $1: 1,706^{18,21}$. This variability is likely to be explained by heterogeneity in study populations and definitions of variant pathogenicity. For example, many previous studies did not include all eight curated genes with strong or moderate disease-gene association but also marked other genes (e.g. TGFB3) with only limited evidence as associated with $\mathrm{ACM}^{19,20}$. In addition, we included both missense and LoF variants whereas prior studies restricted themselves to LoF variants only.

For DCM, little is known about the prevalence of DCM causing variants in the general population. Studies focusing on truncating TTN variants in the general population have found a prevalence ranging between 1:33 and 1:526 depending on the definition of pathogenicity ${ }^{22,23}$. This could in part be due to the changed locations of truncating variants over the years. When solely focussing on (likely) pathogenic $T T N$ variants, we found a prevalence of only 1:735. This differs from the previous studies, probably because not all TTN variants are reported as (likely) pathogenic in ClinVar and VKGL. Including all curated DCM-associated genes, we report a prevalence of 1:251.

For $\mathrm{HCM}$, we found a prevalence ranging between 1:250 and 1:149 individuals carrying a (likely) pathogenic variant, which approaches previous estimates of $1: 207^{24}$. In a recent study, including the UKB population, a prevalence of 1:407 was reported ${ }^{25}$. They included 8 sarcomere-encoding genes described to be associated with HCM (ACTC1, MYBPC3, MYH7, MYL2, MYL3, TNNI3, TNNT2 and TPM1) and variants that were described as (likely) pathogenic in Clinvar or annotated as (likely) pathogenic according to ACMG criteria and filtered variants for an allele frequency of 0.00004 . We included additional genes (CSRP3, JPH2 and TNNC1) and (likely) pathogenic variants from the VKGL database and filtered for a minor allele frequency of 0.001 . 
medRxiv preprint doi: https://doi.org/10.1101/2022.01.06.22268837; this version posted January 6, 2022. The copyright holder for this preprint (which was not certified by peer review) is the author/funder, who has granted medRxiv a license to display the preprint in perpetuity.

It is made available under a CC-BY-NC 4.0 International license .

Disease expression of (likely) pathogenic variants in the general population

Most information on disease penetrance in $\mathrm{ACM}, \mathrm{DCM}$ or $\mathrm{HCM} \mathrm{G}+$ is based on observations in $\mathrm{G}+$ relatives. Previous studies have shown that $37 \%{ }^{21}$ of $\mathrm{ACM} \mathrm{G}+$ relatives and up to $50 \%{ }^{26}$ of $\mathrm{HCM} \mathrm{G}+$ relatives with sarcomeric variants show disease expression during follow-up. Our findings suggest that disease penetrance in the general population is much lower. We found that $1.2 \%$ of $A C M ~ G+, 3.1 \%$ of DCM G+ and $2.6 \%$ of $\mathrm{HCM} \mathrm{G+} \mathrm{in} \mathrm{the} \mathrm{UKB} \mathrm{were} \mathrm{diagnosed} \mathrm{with}$ a cardiomyopathy or heart failure, in the absence of chronic ischemic heart disease. Our additional analysis of ventricular function and ECG in undiagnosed $G+$ subjects also suggests a low disease penetrance. We found significantly worse LVEF and strain parameters in DCM G+P-compared to controls, however none met the diagnostic Henry criteria (LVEF below $45 \%$ and LVEDVi two times the normal SD) ${ }^{16}$. Although CMR data was only available in a subgroup of undiagnosed $\mathrm{G}+$ patients, these findings make it unlikely that the low penetrance found in our study arises from missed diagnoses or covert disease in the G+ cohort. In G+P- ACM and DCM we found a low but significantly higher prevalence of ventricular arrhythmias compared to controls (1.7\% vs. 0.3\% (OR 5.85 [95\% Cl 1.98;14.40]) and $1.0 \%$ vs. $0.3 \%$ (OR $3.43[95 \% \mathrm{Cl} 1.35 ; 7.68)$ ) respectively). In ACM, electrical abnormalities are known to precede structural abnormalities ${ }^{27}$. Therefore, these findings may suggest early disease penetrance in a small subset of undiagnosed $\mathrm{G}+$ individuals. The discrepancy between the high disease prevalence found in G+ family members and the low prevalence in the $\mathrm{G}+$ general population points towards the interaction of possible other (unidentified) genetic and environmental factors leading to this variation in disease penetrance between relatives and general population. 
medRxiv preprint doi: https://doi.org/10.1101/2022.01.06.22268837; this version posted January 6, 2022. The copyright holder for this preprint (which was not certified by peer review) is the author/funder, who has granted medRxiv a license to display the preprint in perpetuity.

It is made available under a CC-BY-NC 4.0 International license .

Interestingly, the South Asian MYBPC3 and the TNNT2 variant, showed a relatively high prevalence in our cohort. In total, $19 \%$ of $\mathrm{HCM} \mathrm{G+} \mathrm{was} \mathrm{Asian} \mathrm{and} \mathrm{mainly} \mathrm{carried} \mathrm{the}$ c.3628-41_3628-17del variant in the MYBPC3 gene. Although this variant is indicated as likely pathogenic in Clinvar, a previous study suggests that this variant may be reclassified as benign ${ }^{28}$. In our study, none of these mutation carriers were diagnosed with HCM. Four were diagnosed with heart failure of whom one was diagnosed with DCM. This suggests that this variant is associated with heart failure in the setting of multiple forms of cardiomyopathy, and not simply $\mathrm{HCM}^{28}$. Second, the c.862C > T p.Arg $288 \mathrm{Cys}$ variant in TNNT2 was previously found in HCM individuals, and is suggested as a non-primary or only cause of $\mathrm{HCM}^{29}$. Interestingly, when excluding these variants from our $\mathrm{G}+\mathrm{P}$ - population, a significantly higher wall thickness is measured compared to control. These two examples emphasize that when (likely) pathogenic variants are identified as a secondary finding, other factors such as the specific variant and the family history are crucial to inform screening frequency.

Interestingly, self-reported health-related quality of life and psychological well-being of 89 asymptomatic HCM knowing to be G+ were previously evaluated in a Dutch cohort and found to be at least similar to the general population, which suggests that reporting incidental findings will not harm psychological well-being of $\mathrm{G}+{ }^{30}$. However, frequent cardiological examination of $\mathrm{G}+$ and family members turning out to be carriers after cascade screening will put a burden on health care and societal costs ${ }^{31}$. Since the overall disease penetration in the general population is quite low, it should be considered to apply a modest frequency of cardiovascular screening in individuals identified after secondary finding and their relatives. It may even be considered to only perform cascade screening 
medRxiv preprint doi: https://doi.org/10.1101/2022.01.06.22268837; this version posted January 6, 2022. The copyright holder for this preprint (which was not certified by peer review) is the author/funder, who has granted medRxiv a license to display the preprint in perpetuity. It is made available under a CC-BY-NC 4.0 International license.

after disease expression is identified, but in all these decisions, family history, gene and variant type should be considered.

\section{Limitations}

Disease expression in inherited cardiomyopathies typically occurs before the age of 40 years. Since the mean age of our cohort was around 60 years, we would expect disease expression to have occured in most of the G+. However, further follow-up of G+Pindividuals is necessary to evaluate if they will develop a cardiomyopathy later in life. On the other hand, since disease expression is present at a younger age, these individuals will be less likely to participate in such large-scale biobank study.

Despite recent efforts to harmonize knowledge on genes associated with inherited cardiomyopathies $^{5-7}$, and guidelines for variant classification ${ }^{31}$, the adjudication of the clinical significance of single variants can still differ between diagnostic laboratories ${ }^{31}$ which has led to interpretation differences. Furthermore, not all (likely) pathogenic variants are reported in these databases, especially family-specific variants and pathogenic variants in non-Caucasian populations are underreported.

\section{Conclusion}

In a cohort of 200,643 individuals with WES and phenotype data we identified a prevalence of pathogenic variants associated with ACM, DCM and HCM of 1:578, 1:251 and 1:149 respectively. Among the identified G+ individuals, cardiomyopathy, heart failure and ventricular arrhythmias were more common compared to G-. However, overall disease penetrance was low (1.2-3.1\%). Therefore, decisions on application of cascade screening 
medRxiv preprint doi: https://doi.org/10.1101/2022.01.06.22268837; this version posted January 6, 2022. The copyright holder for this preprint (which was not certified by peer review) is the author/funder, who has granted medRxiv a license to display the preprint in perpetuity. It is made available under a CC-BY-NC 4.0 International license.

and frequency of cardiological examination should be based on multiple factors, such as variant and gene type, family history and disease expression.

\section{Acknowledgements}

None

\section{Funding sources}

The work was financially supported by the Netherlands Cardiovascular Research Initiative, an initiative supported by the Dutch Heart Foundation (CardioVasculair Onderzoek Nederland (CVON) projects: DOUBLE-DOSE 2020B005, PREDICT2 2018-30, eDETECT 201512), PREDICT Young Talent Program (AtR), 2015 T058 (AtR), 2015T041 (AB) and 2019T045

(MvV and JvS). In addition, MB is supported by the Alexandre Suerman Stipend of the UMC Utrecht (2017), AtR by the UMC Utrecht Fellowship Clinical Research Talent and FA by the UCL Hospitals NIHR Biomedical Research Center.

\section{Disclosures}

None

\section{References}

1. McKenna WJ, Judge DP. Epidemiology of the inherited cardiomyopathies. Nat Rev Cardiol. 2021;18:22-36.

2. Hershberger RE, Hedges DJ, Morales A. Dilated cardiomyopathy: the complexity of a diverse genetic architecture. Nat Rev Cardiol. 2013;10:531-547. 
medRxiv preprint doi: https://doi.org/10.1101/2022.01.06.22268837; this version posted January 6, 2022. The copyright holder for this preprint (which was not certified by peer review) is the author/funder, who has granted medRxiv a license to display the preprint in perpetuity.

It is made available under a CC-BY-NC 4.0 International license .

3. Gersh BJ, Maron BJ, Bonow RO, Dearani JA, Fifer MA, Link MS, Naidu SS, Nishimura RA, Ommen SR, Rakowski H, Seidman CE, Towbin JA, Udelson JE, Yancy CW. 2011 ACCF/AHA guideline for the diagnosis and treatment of hypertrophic cardiomyopathy: executive summary: a report of the American College of Cardiology Foundation/American Heart Association Task Force on Practice Guidelines.

Circulation. 2011;124:2761-2796.

4. $\quad$ Miller DT, Lee K, Chung WK, Gordon AS, Herman GE, Klein TE, Stewart DR, Amendola LM, Adelman K, Bale SJ, Gollob MH, Harrison SM, Hershberger RE, McKelvey K, Richards CS, Vlangos CN, Watson MS, Martin CL. ACMG SF v3.0 list for reporting of secondary findings in clinical exome and genome sequencing: a policy statement of the American College of Medical Genetics and Genomics (ACMG). Genet Med. 2021;23:1381-1390.

5. James CA, Jongbloed JDH, Hershberger RE, Morales A, Judge DP, Syrris P, Pilichou K, Domingo AM, Murray B, Cadrin-Tourigny J, Lekanne Deprez R, Celeghin R, Protonotarios A, Asatryan B, Brown E, Jordan E, McGlaughon J, Thaxton C, Kurtz CL, van Tintelen JP. International Evidence Based Reappraisal of Genes Associated With Arrhythmogenic Right Ventricular Cardiomyopathy Using the Clinical Genome Resource Framework. Circ Genomic Precis Med. 2021;14:e003273.

6. Jordan E, Peterson L, Ai T, Asatryan B, Bronicki L, Brown E, Celeghin R, Edwards M, Fan J, Ingles J, James CA, Jarinova O, Johnson R, Judge DP, Lahrouchi N, Lekanne Deprez RH, Lumbers RT, Mazzarotto F, Medeiros Domingo A, Miller RL, Morales A, Murray B, Peters S, Pilichou K, Protonotarios A, Semsarian C, Shah P, Syrris P, Thaxton $C$, van Tintelen JP, Walsh R, Wang J, Ware J, Hershberger RE. Evidence-Based Assessment of Genes in Dilated Cardiomyopathy. Circulation. 2021;144:7-19.

7. Ingles J, Goldstein J, Thaxton C, Caleshu C, Corty EW, Crowley SB, Dougherty K, Harrison SM, McGlaughon J, Milko L V, Morales A, Seifert BA, Strande N, Thomson K, Peter van Tintelen J, Wallace K, Walsh R, Wells Q, Whiffin N, Witkowski L, Semsarian C, Ware JS, Hershberger RE, Funke B. Evaluating the Clinical Validity of Hypertrophic Cardiomyopathy Genes. Circ Genomic Precis Med. 2019;12:e002460.

8. Landrum MJ, Lee JM, Benson M, Brown GR, Chao C, Chitipiralla S, Gu B, Hart J, Hoffman D, Jang W, Karapetyan K, Katz K, Liu C, Maddipatla Z, Malheiro A, McDaniel K, Ovetsky M, Riley G, Zhou G, Holmes JB, Kattman BL, Maglott DR. ClinVar: improving access to variant interpretations and supporting evidence. Nucleic Acids Res. 2018;46:D1062-D1067.

9. van der Velde KJ, Imhann F, Charbon B, Pang C, van Enckevort D, Slofstra M, Barbieri R, Alberts R, Hendriksen D, Kelpin F, de Haan M, de Boer T, Haakma S, Stroomberg C, Scholtens S, van de Geijn G-J, Festen EAM, Weersma RK, Swertz MA. MOLGENIS research: advanced bioinformatics data software for non-bioinformaticians. Bioinformatics. 2019;35:1076-1078.

10. Petersen SE, Matthews PM, Bamberg F, Bluemke DA, Francis JM, Friedrich MG, Leeson P, Nagel E, Plein S, Rademakers FE, Young AA, Garratt S, Peakman T, Sellors J, 
medRxiv preprint doi: https://doi.org/10.1101/2022.01.06.22268837; this version posted January 6, 2022. The copyright holder for this preprint (which was not certified by peer review) is the author/funder, who has granted medRxiv a license to display the preprint in perpetuity.

It is made available under a CC-BY-NC 4.0 International license .

Collins R, Neubauer S. Imaging in population science: cardiovascular magnetic resonance in 100,000 participants of UK Biobank - rationale, challenges and approaches. J Cardiovasc Magn Reson Off J Soc Cardiovasc Magn Reson. 2013;15:46.

11. Petersen SE, Matthews PM, Francis JM, Robson MD, Zemrak F, Boubertakh R, Young AA, Hudson S, Weale P, Garratt S, Collins R, Piechnik S, Neubauer S. UK Biobank'S cardiovascular magnetic resonance protocol. J Cardiovasc Magn Reson. 2016;18:8.

12. Ruijsink B, Puyol-Anton E, Oksuz I, Sinclair M, Bai W, Schnabel JA, Razavi R, King AP. Fully Automated, Quality-Controlled Cardiac Analysis From CMR: Validation and Large-Scale Application to Characterize Cardiac Function. JACC CardiovasC Imaging. 2019;

13. Cerqueira MD, Weissman NJ, Dilsizian V, Jacobs AK, Kaul S, Laskey WK, Pennell DJ, Rumberger JA, Ryan T, Verani MS. Standardized myocardial segmentation and nomenclature for tomographic imaging of the heart. A statement for healthcare professionals from the Cardiac Imaging Committee of the Council on Clinical Cardiology of the American Heart Association. Int J Cardiovasc Imaging. 2002;18:539542.

14. R Core team. R: A Language and Environment for Statistical Computing [Internet]. 2020;Available from: https://www.r-project.org/

15. Marcus FI, Mckenna WJ, Sherrill D, Basso C, Bauce B, Bluemke DA, Calkins H, Corrado D, Cox MGPJ, Daubert JP, Fontaine G, Gear K, Hauer R, Nava A, Picard MH, Protonotarios N, Saffitz JE, Sanborn DMY, Steinberg JS, Tandri H, Thiene G, Towbin JA, Tsatsopoulou A, Wichter T, Zareba W. Diagnosis of arrhythmogenic right ventricular cardiomyopathy/dysplasia: proposed modification of the task force criteria.

Circulation [Internet]. 2010;121:1533-41. Available from:

http://www.ncbi.nlm.nih.gov/pubmed/20172911

16. Henry WL, Gardin JM, Ware JH. Echocardiographic measurements in normal subjects from infancy to old age. Circulation. 1980;62:1054-1061.

17. Ommen SR, Mital S, Burke MA, Day SM, Deswal A, Elliott P, Evanovich LL, Hung J, Joglar JA, Kantor P, Kimmelstiel C, Kittleson M, Link MS, Maron MS, Martinez MW, Miyake CY, Schaff H V, Semsarian C, Sorajja P. 2020 AHA/ACC Guideline for the Diagnosis and Treatment of Patients With Hypertrophic Cardiomyopathy: Executive Summary: A Report of the American College of Cardiology/American Heart Association Joint Committee on Clinical Practice Guidelines. J. Am. Coll. Cardiol. 2020;76:3022-3055.

18. Carruth ED, Young W, Beer D, James CA, Calkins H, Jing L, Raghunath S, Hartzel DN, Leader JB, Kirchner HL, Smelser DT, Carey DJ, Kelly MA, Sturm AC, Alsaid A, Fornwalt BK, Haggerty CM. Prevalence and Electronic Health Record-Based Phenotype of Lossof-Function Genetic Variants in Arrhythmogenic Right Ventricular CardiomyopathyAssociated Genes. Circ Genomic Precis Med. 2019;12:e002579.

19. Haggerty CM, James CA, Calkins H, Tichnell C, Leader JB, Hartzel DN, Nevius CD, 
medRxiv preprint doi: https://doi.org/10.1101/2022.01.06.22268837; this version posted January 6, 2022. The copyright holder for this preprint (which was not certified by peer review) is the author/funder, who has granted medRxiv a license to display the preprint in perpetuity.

It is made available under a CC-BY-NC 4.0 International license .

Pendergrass SA, Person TN, Schwartz M, Ritchie MD, Carey DJ, Ledbetter DH, Williams MS, Dewey FE, Lopez A, Penn J, Overton JD, Reid JG, Lebo M, Mason-Suares H, AustinTse C, Rehm HL, Delisle BP, Makowski DJ, Mehra VC, Murray MF, Fornwalt BK. Electronic health record phenotype in subjects with genetic variants associated with arrhythmogenic right ventricular cardiomyopathy: a study of 30,716 subjects with exome sequencing. Genet Med. 2017;19:1245-1252.

20. Hall CL, Sutanto H, Dalageorgou C, McKenna WJ, Syrris P, Futema M. Frequency of genetic variants associated with arrhythmogenic right ventricular cardiomyopathy in the genome aggregation database. Eur J Hum Genet. 2018;26:1312-1318.

21. Groeneweg JA, Bhonsale A, James CA, te Riele AS, Dooijes D, Tichnell C, Murray B, Wiesfeld ACP, Sawant AC, Kassamali B, Atsma DE, Volders PG, de Groot NM, de Boer K, Zimmerman SL, Kamel IR, van der Heijden JF, Russell SD, Jan Cramer M, Tedford RJ, Doevendans PA, van Veen TA, Tandri H, Wilde AA, Judge DP, van Tintelen JP, Hauer RN, Calkins H. Clinical Presentation, Long-Term Follow-Up, and Outcomes of 1001 Arrhythmogenic Right Ventricular Dysplasia/Cardiomyopathy Patients and Family Members. Circ Cardiovasc Genet. 2015;8:437-446.

22. Herman DS, Lam L, Taylor MRG, Wang L, Teekakirikul P, Christodoulou D, Conner L, DePalma SR, McDonough B, Sparks E, Teodorescu DL, Cirino AL, Banner NR, Pennell DJ, Graw S, Merlo M, Di Lenarda A, Sinagra G, Bos JM, Ackerman MJ, Mitchell RN, Murry CE, Lakdawala NK, Ho CY, Barton PJR, Cook SA, Mestroni L, Seidman JG, Seidman CE. Truncations of titin causing dilated cardiomyopathy. $N$ Engl J Med. 2012;366:619-628.

23. Akinrinade O, Koskenvuo JW, Alastalo T-P. Prevalence of Titin Truncating Variants in General Population. PLoS One. 2015;10:e0145284.

24. Bick AG, Flannick J, Ito K, Cheng S, Vasan RS, Parfenov MG, Herman DS, DePalma SR, Gupta N, Gabriel SB, Funke BH, Rehm HL, Benjamin EJ, Aragam J, Taylor HAJ, Fox ER, Newton-Cheh C, Kathiresan S, O'Donnell CJ, Wilson JG, Altshuler DM, Hirschhorn JN, Seidman JG, Seidman C. Burden of rare sarcomere gene variants in the Framingham and Jackson Heart Study cohorts. Am J Hum Genet. 2012;91:513-519.

25. de Marvao A, McGurk KA, Zheng SL, Thanaj M, Bai W, Duan J, Biffi C, Mazzarotto F, Statton B, Dawes TJW, Savioli N, Halliday BP, Xu X, Buchan RJ, Baksi AJ, Quinlan M, Tokarczuk $P$, Tayal U, Francis $C$, Whiffin $N$, Theotokis PI, Zhang $X$, Jang $M$, Berry $A$, Pantazis A, Barton PJR, Rueckert D, Prasad SK, Walsh R, Ho CY, Cook SA, Ware JS, O'Regan DP. Phenotypic Expression and Outcomes in Individuals With Rare Genetic Variants of Hypertrophic Cardiomyopathy. J Am Coll Cardiol. 2021;78:1097-1110.

26. van Velzen HG, Schinkel AFL, Baart SJ, Oldenburg RA, Frohn-Mulder IME, van Slegtenhorst MA, Michels M. Outcomes of Contemporary Family Screening in Hypertrophic Cardiomyopathy. Circ Genomic Precis Med. 2018;11:e001896.

27. Gomes J, Finlay M, Ahmed AK, Ciaccio EJ, Asimaki A, Saffitz JE, Quarta G, Nobles M, Syrris P, Chaubey S, McKenna WJ, Tinker A, Lambiase PD. Electrophysiological abnormalities precede overt structural changes in arrhythmogenic right ventricular 
medRxiv preprint doi: https://doi.org/10.1101/2022.01.06.22268837; this version posted January 6, 2022. The copyright holder for this preprint (which was not certified by peer review) is the author/funder, who has granted medRxiv a license to display the preprint in perpetuity.

It is made available under a CC-BY-NC 4.0 International license .

cardiomyopathy due to mutations in desmoplakin-A combined murine and human study. Eur Heart J. 2012;33:1942-1953.

28. Harper AR, Bowman M, Hayesmoore JBG, Sage H, Salatino S, Blair E, Campbell C, Currie B, Goel A, McGuire K, Ormondroyd E, Sergeant K, Waring A, Woodley J, Kramer $\mathrm{CM}$, Neubauer $\mathrm{S}$, Farrall M, Watkins $\mathrm{H}$, Thomson KL, Abraham T, Anderson L, Appelbaum E, Autore C, Berry C, Biagini E, Bradlow W, Bucciarelli-Ducci C, Chiribiri A, Choudhury L, Crean A, Dawson D, Desai MY, Elstein E, Flett A, Friedrich M, Heitner S, Helms A, Ho C, Jacoby DL, Kim H, Kim B, Larose E, Mahmod M, Mahrholdt H, Maron M, McCann G, Michaels M, Mohiddin S, Nagueh S, Newby D, Olivotto I, Owens A, Pierre-Mongeon F, Prasad S, Rimoldi O, Salerno M, Schulz-Menger J, Sherrid M, Swoboda P, van Rossum A, Weinsaft J, White J, Williamson E. Reevaluation of the South Asian MYBPC3 ${ }^{\& \# 394 ; 25 \mathrm{bp}}$ Intronic Deletion in Hypertrophic Cardiomyopathy. Circ Genomic Precis Med. 2020;13:e002783.

29. Ripoll-Vera T, Gámez JM, Govea N, Gómez Y, Núñez J, Socías L, Escandell Á, Rosell J. Clinical and Prognostic Profiles of Cardiomyopathies Caused by Mutations in the Troponin T Gene. Rev Esp Cardiol (Engl Ed). 2016;69:149-158.

30. Christiaans I, van Langen IM, Birnie E, Bonsel GJ, Wilde AAM, Smets EMA. Quality of life and psychological distress in hypertrophic cardiomyopathy mutation carriers: a cross-sectional cohort study. Am J Med Genet A. 2009;149A:602-612.

31. Fontes Marx M, Ataguba JE, de Vries J, Wonkam A. Systematic Review of the Economic Evaluation of Returning Incidental Findings in Genomic Research. Front. public Heal. 2021;9:697381. 


\section{Tables}

Table 1: Baseline characteristics of mutation carriers and controls

\begin{tabular}{|c|c|c|c|c|}
\hline & $\begin{array}{l}\text { ACM } \\
n=347\end{array}$ & $\begin{array}{l}\text { DCM } \\
n=800\end{array}$ & $\begin{array}{l}\text { HCM } \\
n=1,346\end{array}$ & $\begin{array}{l}\text { Controls } \\
n=9,972\end{array}$ \\
\hline \multicolumn{5}{|l|}{ Demographics } \\
\hline Female (\%) & $187(54)$ & $450(56)$ & $720(54)$ & $5,436(55)$ \\
\hline Age, years & $57[50-64]$ & $58[51-64]$ & 56 [49-63] & $57[49-63]$ \\
\hline \multicolumn{5}{|l|}{ Ethnicity (\%) } \\
\hline White & $311(90)$ & $760(96)$ & $1,001(75)$ & $8,288(84)$ \\
\hline Asian & $10(3)$ & $8(1)$ & $251(19)$ & $1,076(11)$ \\
\hline Black & $7(2)$ & $12(2)$ & $22(2)$ & $164(2)$ \\
\hline Other & $17(5)$ & $15(2)$ & $55(4)$ & $348(4)$ \\
\hline \multicolumn{5}{|l|}{ Cardiovascular risk factors } \\
\hline $\mathrm{BMI}, \mathrm{ml} / \mathrm{m}^{2}$ & $26[24-30]$ & $27[24-30]$ & 27 [24-30] & $27[24-30]$ \\
\hline Diabetes (\%) & $35(10)$ & $62(8)$ & $154(11)^{*}$ & $914(9)$ \\
\hline Hypertension (\%) & $116(33)$ & $287(36)$ & $475(35)$ & $3,420(34)$ \\
\hline Hypercholesterolemia (\%) & $86(25)$ & $211(26)$ & $369(27)^{*}$ & $2,416(24)$ \\
\hline Ever Smoked (\%) & $161(46)$ & $371(46)^{*}$ & $543(40)$ & $4,132(41)$ \\
\hline $\begin{array}{l}\text { MET minutes per week, } \\
\mathrm{ml} / \mathrm{kg} / \mathrm{min}\end{array}$ & $\begin{array}{l}2,001[923- \\
3,551]\end{array}$ & $\begin{array}{l}1,695[784- \\
3,536]\end{array}$ & $\begin{array}{l}1,762[848- \\
3,426]\end{array}$ & $\begin{array}{l}1,773[810- \\
3,453]\end{array}$ \\
\hline Family heart disease (\%) & $179(52)^{*}$ & $380(48)$ & $623(46)$ & $4,458(45)$ \\
\hline \multicolumn{5}{|l|}{ Cardiac disease/outcomes } \\
\hline Cardiomyopathy (\%) & $3(0.9)$ & $22(3)^{* *}$ & $27(2)^{* *}$ & $37(0.4)$ \\
\hline DCM (\%) & $2(0.6)$ & $9(1)^{* *}$ & $1(0.1)$ & $14(0.1)$ \\
\hline $\mathrm{HCM}(\%)$ & $1(0.3)$ & $7(1)^{* *}$ & $20(2)^{* *}$ & $8(0.1)$ \\
\hline Heart failure (\%) & $9(3)$ & $36(5)^{* *}$ & $33(3)$ & $182(2)$ \\
\hline Ventricular arrhythmias (\%) & $7(2)^{* *}$ & $13(2)^{* *}$ & $8(1)$ & $33(0.3)$ \\
\hline
\end{tabular}


medRxiv preprint doi: https://doi.org/10.1101/2022.01.06.22268837; this version posted January 6, 2022. The copyright holder for this preprint (which was not certified by peer review) is the author/funder, who has granted medRxiv a license to display the preprint in perpetuity. It is made available under a CC-BY-NC 4.0 International license .

\begin{tabular}{|l|l|l|l|l|}
\hline Atrial arrhythmias (\%) & $7(2)$ & $34(4)^{* *}$ & $32(2)$ & $191(2)$ \\
\hline $\begin{array}{l}\text { Chronic ischemic heart } \\
\text { disease (\%) }\end{array}$ & $35(10)$ & $73(9)$ & $93(7)$ & $725(7)$ \\
\hline $\begin{array}{l}\text { Acute myocardial infarction } \\
(\%)\end{array}$ & $15(4)$ & $27(3)$ & $36(3)$ & $298(3)$ \\
\hline Cardiac arrest (\%) & $0(0)$ & $6(1)$ & $5(0.4)$ & $34(0.3)$ \\
\hline Cardiovascular death (\%) & $11(3)$ & $24(3)^{*}$ & $18(1)$ & $181(2)$ \\
\hline All cause mortality (\%) & $19(6)$ & $56(7)^{*}$ & $62(5)$ & $513(5)$ \\
\hline Cardiac symptoms & $3(1)$ & $3(0.4)$ & $5(0.4)$ & $41(0.4)$ \\
\hline Cardiac problem & $16(5)$ & $30(4)$ & $56(4)^{*}$ & $312(3)$ \\
\hline Angina pectoris & & & & \\
\hline
\end{tabular}

Number (percentages) are given or median [IQR]. * $\mathrm{p}=0.001-0.05$ and $* * p<0.001$ difference compared to the control group. A more elaborate overview of the baseline characteristics are given in Supplementary Table 3.

Abbreviations: $A C M=$ arrhythmogenic cardiomyopathy; $D C M=$ dilated cardiomyopathy; $H C M=$ hypertrophic cardiomyopathy; $B M I=$ body mass index; $M E T=$ metabolic equivalent of task. 
medRxiv preprint doi: https://doi.org/10.1101/2022.01.06.22268837; this version posted January 6, 2022. The copyright holder for this preprint (which was not certified by peer review) is the author/funder, who has granted medRxiv a license to display the preprint in perpetuity. It is made available under a CC-BY-NC 4.0 International license .

\section{Figures}

\section{Figure 1: Included curated genes per cardiomyopathy}

The Venn diagram of curated genes included in this study shows the overlap in genes per cardiomyopathy. Unless otherwise indicated, pathogenicity of genes are classified as definitive. If a superscript $\mathrm{S}$ or $\mathrm{M}$ is given, genes are classified as having a strong or moderate pathogenicity respectively. In the overlapping circles, yellow, black and red colors refer to ACM, DCM, and HCM respectively. Supplementary Table 1 gives an overview of the included genes and pathogenicity classification per gene and abbreviation per gene. Abbreviations: $A C M=$ arrhythmogenic cardiomyopathy; $D C M=$ dilated cardiomyopathy; $H C M=$ hypertrophic cardiomyopathy.

\section{Figure 2: flowchart inclusion of variants}

Flowchart depicting the inclusion of (likely) pathogenic variants associated with arrhythmogenic cardiomyopathy, dilated cardiomyopathy and hypertrophic cardiomyopathy from the Clinvar ${ }^{11}$ and VKGL database ${ }^{12}$.

Abbreviations: $A C M=$ arrhythmogenic cardiomyopathy; $D C M=$ dilated cardiomyopathy; $H C M=$ hypertrophic cardiomyopathy; $V K G L=$ Vereniging Klinische Genetische Laboratoriumdiagnostiek.

\section{Figure 3: Distribution of genes per cardiomyopathy}

Piecharts with the distribution of curated genes for A) arrhythmogenic cardiomyopathy (ACM); B) dilated cardiomyopathy (DCM); C) hypertrophic cardiomyopathy (HCM). Abbreviations of the different genes are given in Supplementary Table 3 Abbreviations: $G+=$ pathogenic variant carrier.

\section{Figure 4: Forest plot cardiac outcomes stratified per inherited cardiomyopathy}

Odds ratios and $95 \%$ confidence interval are given for the associations between cardiac outcomes and ACM, DCM, or HCM pathogenic variant carriers.

Abbreviations: $A C M=$ arrhythmogenic cardiomyopathy; $D C M=$ dilated cardiomyopathy; $G+=$ pathogenic variant carrier; HCM= hypertrophic cardiomyopathy.

\section{Figure 5: overlap cardiac diagnoses per inherited cardiomyopathy}

The Venn diagram of the overlap between cardiomyopathy, heart failure, ventricular arrhythmia and chronic ischemic heart diagnoses in G+ individuals. De numbers in the diagram are the number of individuals.

Abbreviations: $A C M=$ arrhythmogenic cardiomyopathy; $C M=$ cardiomyopathy; $D C M=$ dilated cardiomyopathy; $\mathrm{G+=}$ pathogenic variant carrier; $\mathrm{HCM}=$ hypertrophic cardiomyopathy; $\mathrm{HF}=$ heart failure; $V A=$ ventricular arrhythmias. 
medRxiv preprint doi: https://doi.org/10.1101/2022.01.06.22268837; this version posted January 6, 2022. The copyright holder for this preprint (which was not certified by peer review) is the author/funder, who has granted medRxiv a license to display the preprint in perpetuity. It is made available under a CC-BY-NC 4.0 International license .

\section{Figure 6: CMR parameters stratified per inherited cardiomyopathy}

Boxplots of CMR parameters to show the distribution of CMR parameters stratified in controls and individuals with a pathogenic variant associated with ACM, DCM, or HCM. Abbreviations: $A C M=$ arrhythmogenic cardiomyopathy; $D C M=$ dilated cardiomyopathy; $E D V i=$ body surface area corrected end-diastolic volume; $E F=$ ejection fraction; $G+=$ pathogenic variant carrier; $H C M=$ hypertrophic cardiomyopathy; $L V=$ left ventricular; $R V=$ right ventricular. 
medRxiv preprint doi: https://doj.org/10.1101/2022.01.06.22268837; this version posted January 6, 2022. The copyright holder for this preprint (which was hot certified by peer review) is the author/funder, who has granted medRxiv a license to display the preprint in perpetuity.

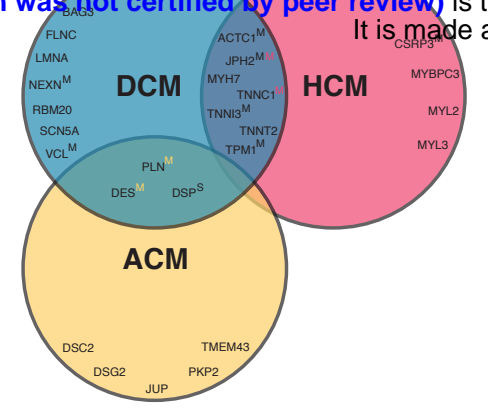




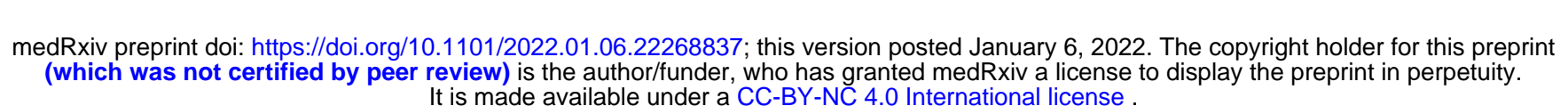

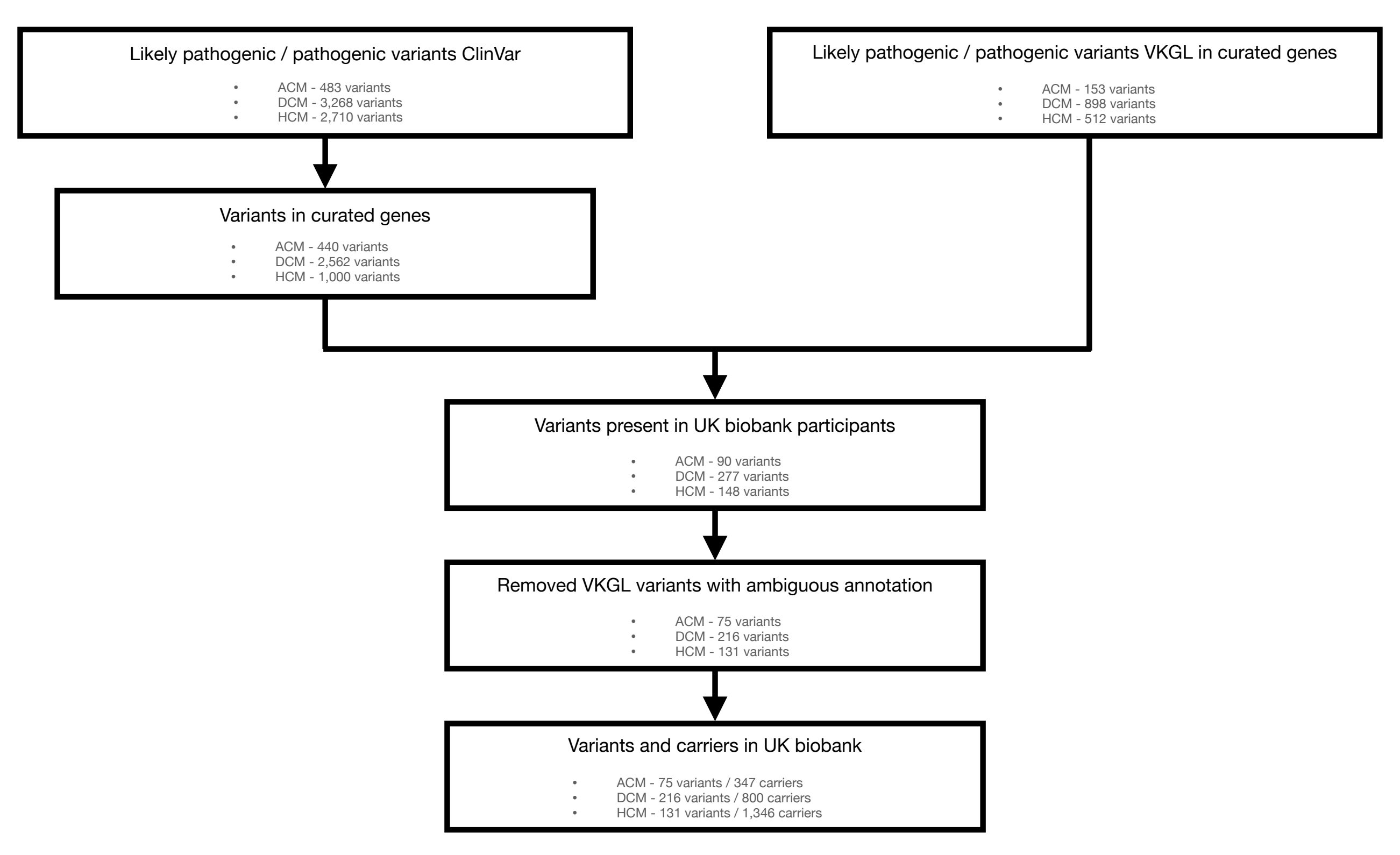


medRxiv preprint doi: https://doi.org/10.1101/2022.01.06.22268837; this version posted January 6, 2022. The copyright holder for this preprint (which was not certified by peer review) is the author/funder, who has granted medRxiv a license to display the preprint in perpetuity. It is made available under a CC-BY-NC 4.0 International license.

A) ACM

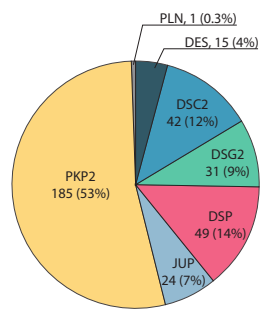

B) DCM

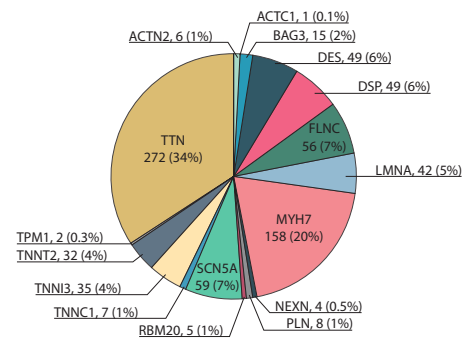

C) HCM

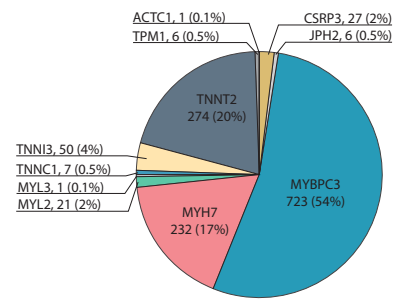


Outcomes

\section{OR $(95 \% \mathrm{Cl})$}

Heart failure

Cardiomyopathy

Heart failure + cardiomyopathy

Phenotype positive

Ventricular arrhythmias

Atrial arrhythmias

Heart arrhythmia

Chronic ischemic heart disease

Angina pectoris

Cardiovascular death

All cause mortality

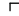

0.12

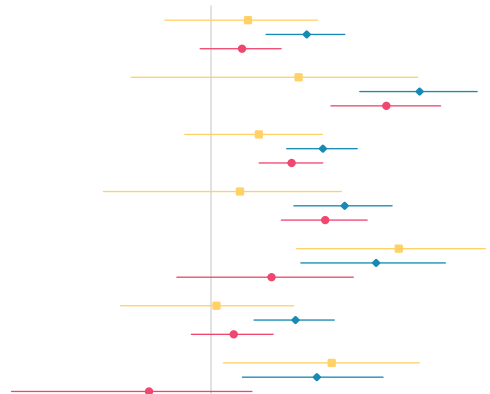

$$
\begin{array}{r}
1.43(0.64 ; 2.81) \\
2.53(1.71 ; 3.67) \\
1.35(0.90 ; 1.98) \\
2.34(0.46 ; 7.45) \\
7.59(4.24 ; 13.28) \\
5.50(3.21 ; 9.31) \\
1.59(0.77 ; 2.95) \\
2.97(2.09 ; 4.14) \\
2.19(1.60 ; 2.96) \\
1.32(0.35 ; 3.55) \\
3.66(2.24 ; 5.81) \\
3.03(1.98 ; 4.56) \\
6.20(2.30 ; 14.38) \\
4.97(2.39 ; 9.75) \\
1.80(0.72 ; 3.99) \\
1.05(0.42 ; 2.24) \\
2.27(1.52 ; 3.31) \\
1.25(0.83 ; 1.83) \\
3.23(1.13 ; 7.57) \\
2.80(1.36 ; 5.32) \\
0.55(0.14 ; 1.49) \\
1.43(0.97 ; 2.05) \\
1.28(0.98 ; 1.65) \\
0.95(0.75 ; 1.19) \\
1.50(0.83 ; 2.51) \\
1.21(0.79 ; 1.77) \\
1.34(0.99 ; 1.80) \\
1.77(0.86 ; 3.29) \\
1.67(1.04 ; 2.59) \\
0.73(0.42 ; 1.20) \\
1.07(0.63 ; 1.71) \\
1.39(1.02 ; 1.85) \\
0.89(0.67 ; 1.17) \\
\end{array}
$$




\section{B) $\mathrm{DCM} \mathrm{G}_{+}$}


B

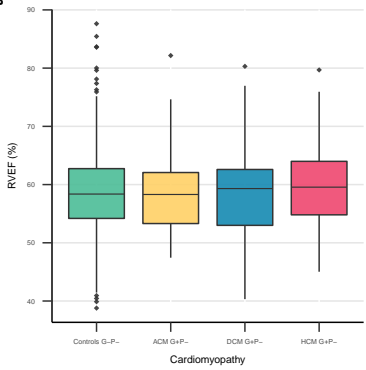

C

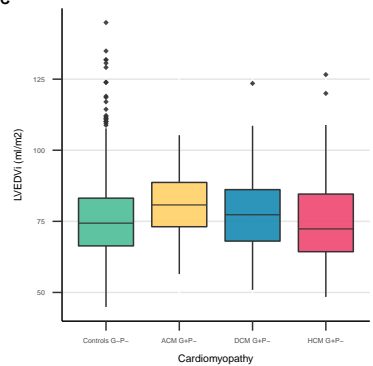

E

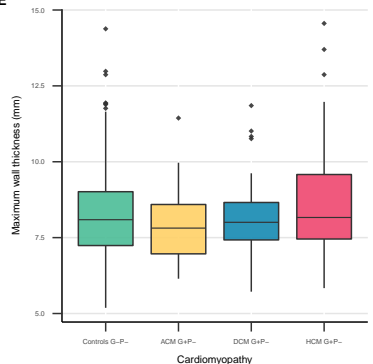

D

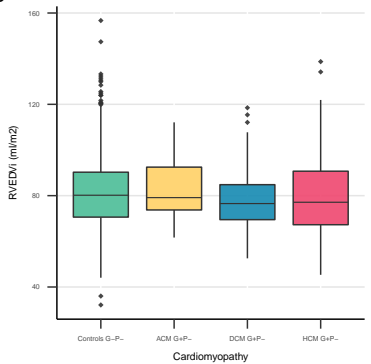

F

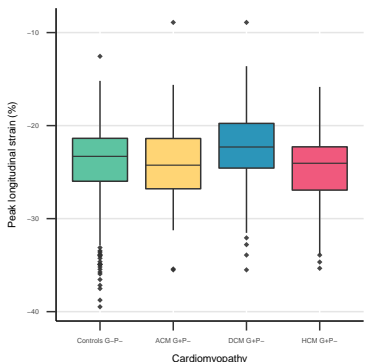

